\title{
CLINOPYROXENE GEOTHERMS FOR THE MANTLE COLUMNS BENEATH KIMBERLITE PIPES FROM SIBERIAN CRATON
}

Igor Ashchepkov ${ }^{1}$, Nikolai Vladykin ${ }^{2}$, Nikolai Pokhilenko $^{1}$, Nikolai Sobolev ${ }^{1}$, Elena Malygina ${ }^{1}$, Sergei Kuligin $^{1}$, Yuri Ovchinnikiv ${ }^{1}$, Nikolai Afanasiev ${ }^{1}$, Gregorii Mkrtychan ${ }^{3}$, Anatolii Rotman ${ }^{4}$, Lyudmila Pokhilenko $^{1}$, Alla Logvinova ${ }^{1}$, Ol'ga Khmel'nikova ${ }^{1}$, Sergei Kostrovitsky ${ }^{2}$, Aleksandr Tolstov . ${ }^{1}$ United Institute of Geology Geophysics Mineralogy SD RAS, Russia, ${ }^{2}$ Institute of Geochemistry SD RAS, Russia;

${ }^{3}$ Krasnoyarsk Diamond Prosp. Expedition, Russia; ${ }^{3}$ YANUGP CNIGRI ALROSA, Russia

\section{INTRODUCTION}

Thermal structure of mantle beneath kimberlite pipes under Siberian craton is not clear in detail. Precision of the garnet thermobarometry used by Griffin and colleagues $(1996,2002)$ marked general tendencies of mantle construction. Previous thermobarometric study gave smooth geotherm (Boyd et al, 1997). Lack of fresh xenoliths in some pipes restricts the detail PT reconstruction. Orthopyroxene thermobarometry (Brey, Kohler, 1990 - McGregor, 1974) produce the best geotherms (Kopylova et al, 1999) but do not allow PT estimates for eclogites as well as $\mathrm{Cr}-\mathrm{Cpx}$ thermobarometry (Nimis, Taylor, 2000).

We used pyroxene barometer Jd-Di (Ashchepkov, 2002) especially compiled to produce the geotherm comparable with and Cr-Cpx (Nimis, Taylor, 2000) to determine thermal conditions and mantle structure beneath kimberlite pipes from Siberian craton.

\section{LAYERING IN THE MANTLE}

\section{PALEOZOIC STAGE}

\section{Udachnaya}

Large middle Paleozoic pipes Udachnaya (Pokhilenko, 1977; Boyd et al, 1997), Yubileynaya, Mir (Spetsius, 2001; Roden, Lasko, 1995; Beard et al, 2000) reveal distinct layering but varying compositions (Fig.1). Comparison of the TP estimates based on Opx and Cpx methods allow to reconstruct the structure for the most well studied pipe Udachnaya (Pokhilenko et al., 1991, 2000, Boyd et al., 1997; Kuligin et al., 2000, Malygina, 2002, dissertation) Recalculated using OPx (Brey,
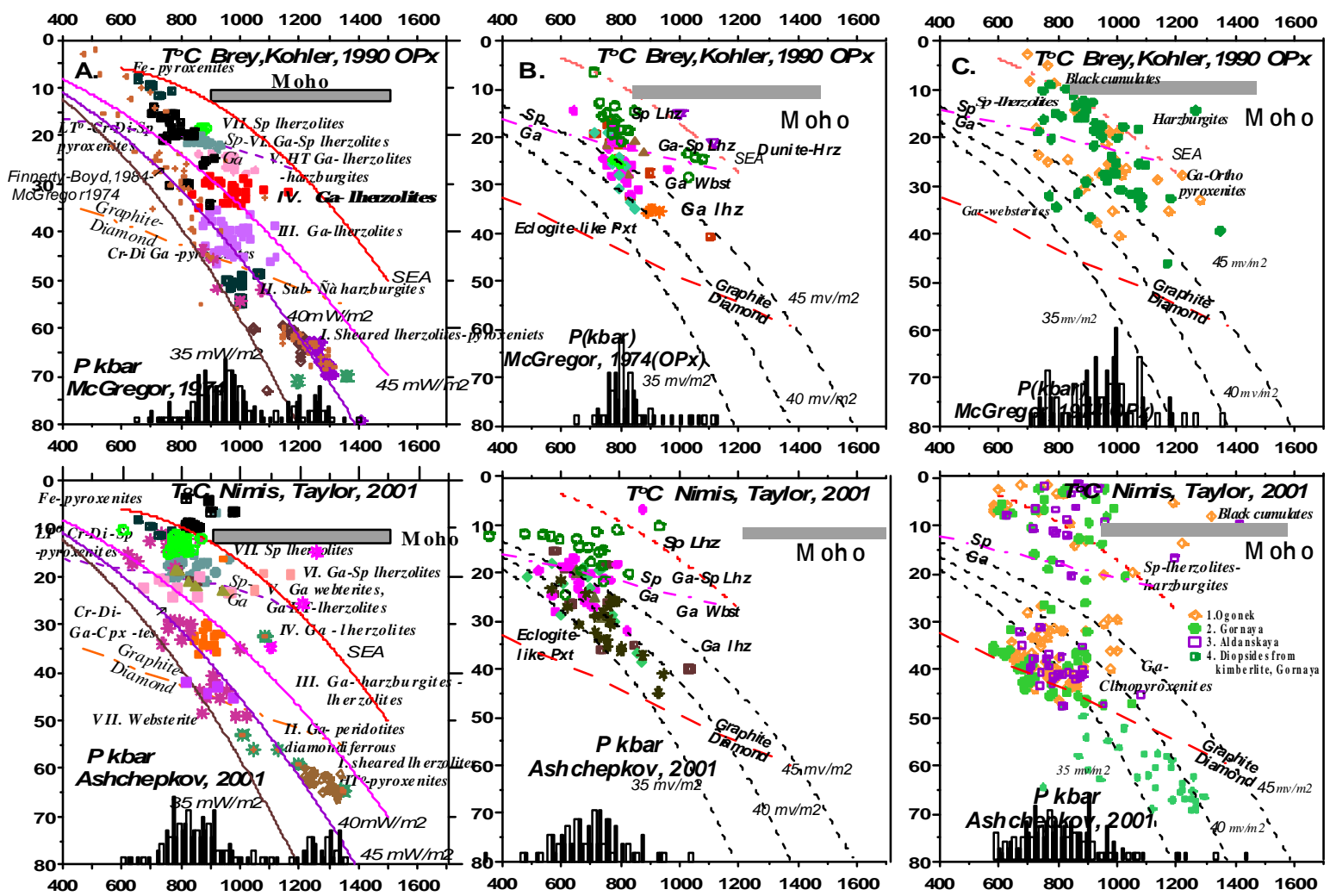

Figure 1: Reconstructed with Opx and Cpx thermobarometry mantle sections beneath: A:.Udachnaya 
Kohler, 1990-McGregor, 1974) and Cpx (Nimis, Taylor- Ashchepkov, 2001) thermobarometry all data of xenoliths reveal complex mantle layering (Fig1.A). The HT layer (I) (70-60 kbar) with two PT trends for sheared fine-grained peridotites gives the inflection of geotherm to $40-42 \mathrm{~mW} / \mathrm{m}^{2}$. (II) $(60-45 \mathrm{kbar})$ - coarsegrained cold (diamondiferous) garnet peridotites - close to $35 \mathrm{~mW} / \mathrm{m}^{2}$ conductive geotherm. 'Deep' Galherzolites (III) (45 to $35 \mathrm{kbar}$ ) deviates to $38-40$ $\mathrm{mW} / \mathrm{m} 2$ thermal gradients. (IV) (35-27 kbar) common Ga-lherzolites are dispersed from 35 to 50 (average 45) $\mathrm{mW} / \mathrm{m}^{2}$. (V) - hot Ga lherzolites (27-20 kbar) are slightly above conductive geotherm $50 \mathrm{~mW} / \mathrm{m}^{2}$ as well as Ga-Sp lherzolites group (VI) (23-20kbar). (VII) Splherzolites are rare. HT-eclogites occur within thermally excited layer (I). Subduction eclogites locate at the bottoms of layers II- III. Ga- Cr-Di websterites occur in deep zones rarely but trace boundaries of Gaand $\mathrm{Ga}-\mathrm{Sp}$ lherzolites (20-23kbar), the Ga-Sp transition ( 20kbar) and are highly distributed above. Fe- Gapyroxenites underlie the Moho boundary. $\mathrm{Cr} \#$ in spinel, $\mathrm{Cr}$ and $\mathrm{Ca}$ in garnet demonstrate good correlation with estimated pressure for the saturated compositions. ÄQFM LogFO 2 increases upward gradually $(-3-0,5)$ with higher values for porhyroclastic lherzolites and sheared varieties. The heating upper $30 \mathrm{kbar}$ are likely correspondent to plume impact in Middle Paleozoic producing the melting, decomposition of garnet, melt migration, creation of pyroxenites in mantle and a dyke swamp at the surface.

\section{Yubilenaya}

In mantle section beneath Yubileynaya peridotites and Cr-Di pyroxenites and Amph- Phl metasomatites with $\mathrm{Na}-\mathrm{Cr}$ rich compositions prevail. Cpx geotherm reveal divide at 35 kbars. Three lherzolitic units below this boundary correspond to $40 \mathrm{mv} / \mathrm{m}^{2}$ geotherm at the upper part and are close to $35 \mathrm{mv} / \mathrm{m}^{2}$ at the lower part (Fig.2.b). Upper geotherm part is more dispersed irregularly deviating to LT conditions. The inflection to hot 'asthenospheric' branch to $1350^{\circ} \mathrm{C}$ was found in the 55-65 kbar cold branch is also traced by several points. Sequence upper $35 \mathrm{kbars}$ is represented by Ca-Tienriched peridotites- pyroxenites judging from garnet and CPx compositions. The middle horizon is represented by highly alkaline clinopyroxenes associated with abundant phlogopite and amphibole. Lower unites are represented by $\mathrm{NaCr}$ - rich $\mathrm{CPx}$ (3$4 \%$ each) and $\mathrm{Ca}-\mathrm{Fe}$ enriched garnets. Sub- $\mathrm{Ca}$ garnets reveal presence of harzburgites in each three units and relic unmetasomitised lherzolite fragments rare occurring in CPx concentrate. Amphiboles in upper part (< $35 \mathrm{kbar}$ ) belonging to pargasites are $\mathrm{Ca}$-rich while in lower part belong to richterite-kataforite groups The $\mathrm{Na}-\mathrm{Cr}$ content in pyroxene rises with pressure according to both $\mathrm{Jd}-\mathrm{Di}$ and $\mathrm{Cr}$ in $\mathrm{Cpx}$ barometry.

\section{Zarnitsa}

Sepentinizated peridotites from this pipe restricted PT estimates. Both clinopyroxene and orthopyroxene thermbarometry display three units. Lower horizon beneath 55-60 kbar is heated. (Fig.2.a) Uooer interval to $40 \mathrm{kbar}$ is missed and probably is represented by dunite- harzburgites and minor eclogites. The horizon near $40 \mathrm{kbar}$ is represented by the moderately depleted in incompatible pyroxene compositions and probably corresponds to the depleted lherzolites. Upper part of the section is traced by several points. Judjing from the garnet composition the construction of Zarnitsa mantle column should be layered and close to those from the nearest pipes (Pokhilenko, Kostrovitsky, unpublished).

\section{Irelyahskaya and Dolgozhdannaya}

Closely located to Udachnaya Irelyahskaya and Dolgozhdannaya pipes contain more clinopyroxenerich layers at the $40-65 \mathrm{kbar}$ interval of mantle column and do not carry abundant shallow mantle peridotites. The new variant of Na-Al CPx (Ashchepkov, 2003) barometry display more irregulary heated and more shallow part of the geotherm. (Fig.2.e)

\section{Mir}

Combining data from literature (Spetsius, 2001; Beard et al; 2000; Roden, Las'ko, 1995 and unpublished data) general structure of Mir pipe represent the marble eclogite - primitive metasomatic lherzolites layers. For Mir the geotherm is constructed at the shallow depth by eclogites - pyroxenite mixture with lherzolites and Phlperidotites in the middle part 30-50 kbar mixed with Na-rich pyroxenites as well as in the other pipes and dunite - harzburgites constituting the deeper part of section. The Opx- Garnet-Ilmenite intergrowths correspond to 60kbar while the megacrystalline $\mathrm{Ga}-\mathrm{Ilm}$ (Cr- bearing assemblages) are close to $40 \mathrm{kbar}$. (Fig.2.c) 


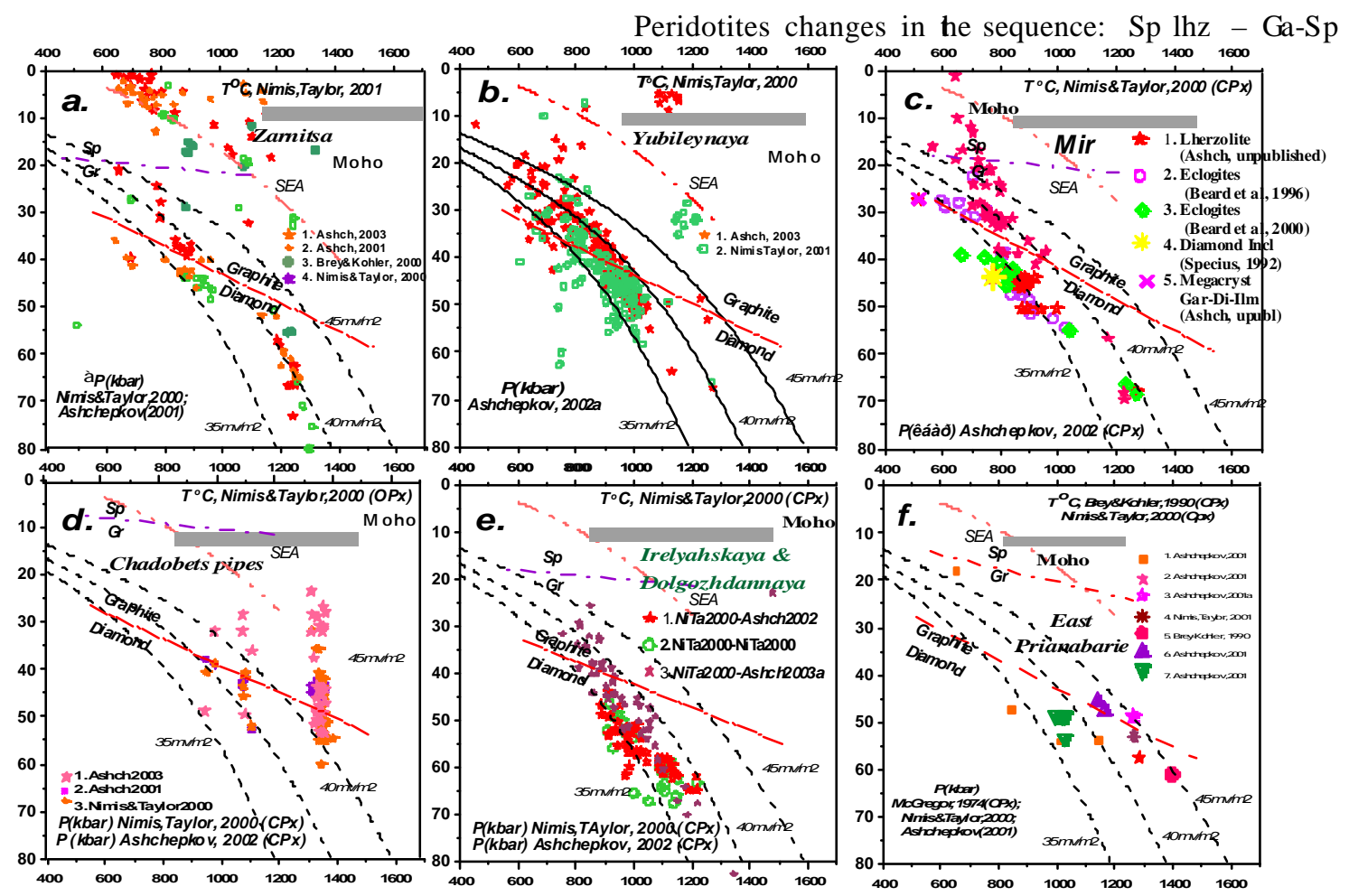

Figure 2: Reconstructed with $\mathrm{Opx}$ and $\mathrm{Cpx}$ thermobarometry mantle sections between: different pipes from Siberian craton

\section{Summary}

Thus general regularities for Paleozoic pipes are: Feenriched lherzolite - pyroxenite horizons upper $35 \mathrm{kbar}$, metasomatic and $\mathrm{Cr}$ - diopside anatexic websterites near 40 kbar increasing the degree of depletion with the depth in general to 60kbar. Deformed peridotites (slightly $\mathrm{Fe}$ - enriched) associated with hot eclogites (Ga-websterites) typical for $60 \quad-70$ kbar interval everywhere..

\section{MESOZOIC STAGE}

Mesozoic kimberlite volcanism take place mainly at the peripheral regions pof Siberian platfor, in Prianabarie, Aldan shield (Chompolo area), and Chadobets uprise (Mcrtychan, unpublished) All kimberlite pipes in studied regions have mantle roots starting from $40 \mathrm{kbar}$ or tracing diamond - graphite stability line.

\section{Obnazhennaya}

Most well studied Obnazhennaya pipe (Ovchinnikov, 1991, dissertation) represent the column without sharp stratification. (Fig.1.b). Amount of pyroxenites and their Na-Al- $\mathrm{Cr}$ content increase to the depth. lhz, Ga-Ol webs, Ga- lherzolites. Eclogites trace the low temperature branch the ilmenite bearing $\mathrm{Fe}$ depleted peridotites close hot branch.

\section{Aldan}

Post Permian-Jurassic plume pipes in Chompolo field has irregular heated starting from $40 \mathrm{kbar}$ mantle columns. Cold branch is represented by $\mathrm{Cr}$-diopside pyroxenites. In shallow level the geotherm is splitting to SEA type branch and cold branch crossing conductive geotherms. Heating is associated with high $\mathrm{Fe}-\mathrm{Ti}-\mathrm{Al}$ enrichment probably related to the plum melt interaction. Cold branch corresponds to very mg-rich pyroxenes high in $\mathrm{Na}-\mathrm{Cr}$ (to $4 \%$ ). Lower part is constructed from depleted $\mathrm{Fe}$ - enriched dunites. (Fig.1.C)

\section{Prianabarie}

Mantle peridotites here are highly depleted. All the spinel facie harzburgites are serpentinized probably in mantle. Eclogites and transitional pyroxenites occurs in the 35-40 kbar interval. Lower part is very irregular heated and is represented by coarse grained dunites with the nests of garnets - two pyroxenes correspondent to the depth 60kbar. The Fe - enriched Ilm glimmerites are common in dunites. (Fig.2.f) 


\section{Chadobets uprise}

Here garnets peridotites were found in newly discovered pipes (Mcrtychan et al, unpublished) In Chadobets upwelling the kimberlites carry pyroxenes from the unusually heated to $1350 \mathrm{oC}$ peridotites. (Fig.2.d) The more cold rocks trace the graphite diamond boundary supposing irregular heating of mantle column. Here the $\mathrm{Fe}$ - metasomatism is not found like it is typical for Chompolo field in Aldan.

\section{COMPARISION MINERAL DATA}

\section{GARNETS}

Comparison with the $\mathrm{Cr}_{2} \mathrm{O}_{3}-\mathrm{CaO} \%$ diagram (Sobolev, 1977) where the $\mathrm{Cr}$ - axe, in general corresponding to the depth, shows very well agreement with the data obtained with the mineral thermobarometry. Amount of the groups for garnets in Yubileinaya, Udachnaya, Zarnitsa and the gaps between the intervals agree well with those on the in PT diagrams. The enrichment in $\mathrm{Fe}-\mathrm{Ti}$ and trace element components (Griffin et al., 1999) helps to reconstruct the litthology of mantle peridotite layers. The divergence of the $\mathrm{CaO}$ content of the garnets with the decreasing pressure - reflect the marble cake - lherzolite - dunite - pyroxenites eclogite layering becaming more sharp with the depth. The common inflection in the $4 \% \quad \mathrm{Cr}_{2} \mathrm{O}_{3}$ in the Sobolev's diagram reflect the changes in the mantle stratigraphy and presence of the metasomatic anatexic associations. In general this coincides with the depth of dehydration of peridotite in subducted mantle wedges (van Keken et al., 2002).

\section{SPINELS}

Spinel groups in general repeat the regularities for the garnets in amount. But the histogram peaks for the $\mathrm{Cr}$ rich varieties is much higher due to the wider occurrence of spinels in dunites. Most Fe-rich and Ti rich associations occurs mainly among $\mathrm{Cr}$ - rich varieties and an opposite in the low -Cr ones.

\section{ILMENITES}

In all studied pipes amount of ilmenites groups also coincides with the determined amount of the mantle horizons. Ilmenite trends correspond to the fractionation and AFC lines (Moor, 1992; Neal 1995). Thus continuous trends relflect the rising of the protokimberlite (sometimes carbonatite) magma forming the feeding system in the pre-eruption stages. The $\mathrm{Cr}$ - rich associations corrsponds to the metasomatic peridotites (Gregory et al, 2002)

\section{SPATIAL REGULIARITIES}

The regularities revealed by Griffin et al (1999) with the submerging of the eclogite mantle layers from the $\mathrm{NE}$ to the central part of Siberian craton in general found the agreement with the pyroxene thermobarometry but later is more detail. Close located pipes sometimes have varying mantle section possibly due to the inclined or sub- vertical positions of eclogite and other bends. The difference in composition of mantle column in Alakit and Daldyn kimberlite fields corresponds to the variation between the high scale K$\mathrm{Na}$ (LILE, Th, U, Ba) metasomatism (continental crust subduction related) and depleted mantle more restricted $\mathrm{Na}$ metasomatism related to oceanic crust subduction $(\mathrm{U}, \mathrm{Pb}, \mathrm{Sr}, \mathrm{Na}$ ). Sometimes type of metasometism may changes in the mantle column. Lower depleted horizons are subjected to the high scale LILE eriched malt-luid percalation with the chromatographic minimas for the minerals.

Marginal parts of craton are in general more depleted but contain thick anatexic and other pyroxenite layers. Developing in time reveals thinning and heating of the mantle columns (Pokhilenko et al, 2002; O'Reilly et al, 2001; and this paper).

\section{CONCLUSIONS}

Pyroxene thermobaromatry agrees very well with the data for the mantle layering obtained by the garnet thermobarometry (Ryan, 1996) poly phase mineral thermobarometry (Brey, Kohler, 1990; Nickel- Green, 1985 etc.) and give the clues for the detail reconstruction even using only concentrate in highly serpentinized pipes. Supported by RFBR grants 99-0565688, 00-05-65288; 01-05-65170; 02-05-64248;0305-64146.

\section{REFERENCES}

Ashchepkov, I., Vladykin, N., Ovchinnikov, Yu., Anoshin, G., Gerasimov, P., Saprykin, A. 2000. Thermal Gradient, Mantle Layering and Geochemistry beneath Aldan Shield According to the Kimberlitic Deep Seated Disintegrated Inclusions. J.Confer. Abstr.,.5/2., pp.162-163

Ashchepkov, I.V., 2002. An Empirical Clinopyroxene Thermobarometer for Mantle Rocks Based on the Jadeite-Diopside Exchange. Trans. (Doklady) RAS (ESS), 382.(1), pp.78-82.

Ashchepkov, I.V., Vladykin, N.V., Saprykin, A.I., Khmelnikova, O.S., 2001. Composition and thermal structure of the mantle in peripheral parts of the 
ancient shields within Siberian craton. Revista Brasileira de Geociencias, 31(4), pp. 527-636

Beard, A.D., Downes, H., Hegner, E., Sablukov, S.M. 2000.Geochemistry and mineralogy of kimberlites from the Arkhangelsk Region, NW Russia: evidence for transitional kimberlite magma types. Lithos. $51 \mathrm{pp}$. 47-73.

Boyd, F.R., Pokhilenko, N.P., Pearson, D.G., Mertzman, S.A., Sobolev, N.V., Finger, L.W., 1997. Composition of the Siberian cratonic mantle: evidence from Udachnaya peridotites xenoliths. Contrib. Mineral. Petrol., 128, pp.228-246.

Brey, G.P., Kohler, T., 1990 Geothermobarometry in four phase lherzolites II: new thermo-barometers and practical assessment of using thermobarometers. J.Petrol., 31, pp.1353-1378

Gregoire M., Bell, D.R.; Le Roex, A.P. 2002. Trace element geochemistry of phlogopite-rich mafic mantle xenoliths: their classification and their relationship to phlogopite-bearing peridotites and kimberlites revisited Contrib Mineral Petrol. 142(5) pp. 603-625.

Griffin, W.L., Ryan, C.G., Kaminsky, F.V., O'Reilly, S.Y., Natapov, L.M., Win, T.T., Kinny, P.D., Ilupin, I.P. 1999. The Siberian lithosphere traverse: mantle terranes and the assembly of the Siberian Craton. Tectonophysics, 310, pp. 1-35.

Kopylova, M.G., Russell, J.K., Cookenboo H. 1999. Petrology of peridotite and pyroxenite xenoliths from the Jericho kimberlite: Implications for the thermal state of the mantle beneath the Slave craton, northern Canada. J. Petrol. 40(1). pp. 79-104.

Kuligin, S.S., Pokhilenko, N.P. 1998 Mineralogy of xenoliths of garnet pyroxenites from kimberlite pipes of Siberian platform. Extended Abstracts 7IKC. Cape Town. pp.480- 482.

MacGregor, I.D. 1974. The system MgO-Al2O3-SiO2: solubility of $\mathrm{Al} 2 \mathrm{O} 3$ in enstatite for spinel and garnetspinel compositions. Am. Mineral. 59:110-19.

Moor, R.O., Griffin, W.L. Gurney et al. 1992 Trace element geochemistry of ilmenites megacrysts from the Monastery kimberlite, South Africa. Lithos. 29, pp.118.

Nimis, P., Taylor, W. 2000. Single clinopyroxene thermobarometry for garnet peridotites. Part I. Calibration and testing of a Cr-in-Cpx barometer and an enstatite-in-Cpx thermometer. Contrib. Mineral. Petrol. 139(5), pp. 541-554.

Nixon, P.H., Boyd, F.R. 1973. Petrogenesis of the granular and sheared ultrabasic nodule suite in kimberlite. / Ed.: Nixon, P.H. Lesotho Kimberlites. Cape and Transvaal, Cape Town. pp. 48-56.

O’Reilly, S.Y., Griffin, W.L., Djomani, P., Y.H., Morgan, P. 2001 Are Lithosphere Forever Track-ing Changes in Subcontinental Lithospheric Mantle Through Time. GSA Today 11/4: 4-9.

Pearson, D.G. 1999. The age of continental roots. Lithos 48:171-194.

Pokh1lenko, N. P., Sobolev, N.V., Kuligin, S. S., Shimizu, N. 2000. Peculiarities of distribution of pyroxenite paragenesis garnets in Yakutian kimberlites and some aspects of the evolution of the Siberian craton lithospheric mantle. Proceedings of the VII International Kimberlite Conference. The P.H. Nixon volume. Pp. 690-707.

Pokhilenko, N.P., Pearson, D.G., Boyd, F.R., Sobolev N.V.1991. Megacrystalline dunites: sources of Siberian diamonds. Camegie Inst. Wash. Yearb. 90: $11-18$

Roden, M.F., Laz'ko, E.E., Ponomarenko A.I., Serenko V.P.Mineralogy of peridotite xenoliths from the Mir kimberlite, Yakutia, Russia . 5 IKC Axetended Abstracts. Novosibirsk, 1995.pp. 462-464

Ryan, C.G., Griffin, W.L., Pearson, N.J., 1996. Garnet geotherms: Pressure -temperature data from Cr-pyrope garnet xenocrysts in volcanic rocks. J. Geophys. Res. 101, pp. 5611-5625.

Spetsius, Z.V. 2002. A xenolith of high-temperature diamondiferous peridotites from the Udachnaya kimberlite pipe. Dokl (Transact) RAN (ESS), v.379 pp. 550-552.

van Keken, P. E. , Kiefer, B., Peacock, S.M. 2002. Highresolution models of subduction zones: Implications for mineral dehydration reactions and the transport of water into the deep mantle. Geochemistry, Geophysics, Geochemistry v. 3, N 10

Contact: IV Ashchepkov, 630090, Novosibirsk -90, academ.VA Koptyug ave.3, Russia, E-mail:

Igor.Ashchepkov@uiggm.nsc.ru 